\title{
Developing Android-Based English Learning Material
}

\author{
Syaifudin Latif Darmawan ${ }^{1}$ Lilik Wariyanti ${ }^{2}$ \\ Muhammadiyah University of Metro \\ Lilikwariyanti78@gmail.com
}

\begin{abstract}
This research aims to find out what the product of English materials at tenth grade of SMA N 1 Metro and to know the experts' validation and students' acceptability on Android-based English materials. The type of this research is Research and Development. The researcher uses ADDIE model. The subjects are 32 students in X IPS 2 class. The data collecting technique is using questionnaire and interview. The data analysis technique is descriptive analysis. The result indicates that (1) the validation of material expert I on android-based English material in content aspect obtained a total score of 94 and aspect of language obtained a total score of 96 is in a very good category. Furthermore, the result of expert II in content aspect obtained a total score of 92 and aspect of language obtained a total score of 88 is in a very good category; (2) the validation of media expert I in view aspect obtained a total score of 93 and aspect of presentation obtained a total score of 100 is in a very good category. Whereas the result of expert II in view aspect obtained a total score of 83 and aspect of presentation obtained a total score of 95 is in a very good category; (3) the students' responses on android-based English material is in a very good category with the percentage of $96 \%$. It can be concluded that Android-based English material is very easily to use at SMAN 1 Metro. The researcher recommends for the next researcher to develop Android-based English material with other design.
\end{abstract}

Key Words: Android, English Learning Material

\section{INTRODUCTION}

Along with the rapid development of the era and global challenges, human resources must continue to be improved. The rapid developments of the era accompanied are increasingly sophisticated technological developments also has an impact on the world of education. Thus 
Developing Android-Based English Learning Material For Students At Tenth Grade Of Senior High School

Syaifudin Latif Darmawan ${ }^{1} \&$ Lilik Wariyanti ${ }^{2}$

Indonesia must prepare qualified human resources to compete in various sectors. Here English has a very an important role to play in the globalization era. Moreover, English lessons must be improved in the schools to produce millennial generations that answer the challenges of the world. Besides that, English also is one of obligatory subjects that must be followed by students in the school. In addition, Depdiknas (2010,p.11) the school curriculum in Indonesia states that by the end of the third grade of junior high school students are expected to recognize and understand about 1000 English words and about 2500 English words for senior high school so that the quality of English must be improved. In fact, the result of observations undertaken by the researcher through doing observation and interviews toward the English teacher Hirni in Senior High School N 1 Metro, the researcher found some problems which become the major obstacles about the English learning process. The problems such as; (1) the unavailability of English learning materials design that the students' need and interest related to the materials; (2) the materials are not given explanation clearly; (3) the students have low motivation; (4) the lack of utilization of effective and innovative teaching-learning media; (5) the method to learn English is still using conventional method. It, of course, becomes a problem in achieving the learning objectives. There are some concept of theory that related to this research. Android is a software used on mobile devices (running devices) including operating systems, middleware and core applications. Android has advanced features that provide many applications to help complete human tasks and also widely used in this era because android can access information quickly and easily (Tarmizi 2013, p.177).

Aritonang (2014, p.11) state that android has several advantages over other operating systems include:

1. In application availability, android based Linux makes it easy for programmers to create new application that are freely distributed with open source licenses, shareware, or even freeware.

2. Android is open platform or not tied to one of the hardware manufactures or one of the operators.

3. Android is cross-compatibility which means it can run with many screen size and resolution. In addition, android has tools that help users build cross-compatible applications.

Meanwhile, Lazareska (2017, p.117) state that android has several disadvantages include: 
1. Android depending on the mobile operator of the user who is testing the new versions depends when the new updates are going to be provided.

2. Android ease of use is lower than iOS.

According to Tomlinson (2015, p.66) materials development is both a field of study and a practical undertaking. As a field, it studies the principles and procedures of the designed, implementation and evaluation of language teaching materials. As a practical undertaking, it refers to anything which is done by writers, teacher or learners to provide source of language input to exploit those source in ways which maximize the likelihood of intake and to simulate purposeful output. Materials allow the students to fulfill learning needs more systematic to the competencies that achieved.

Tomlinson (2011, p.43) state that there are three procedures in the development of learning materials which consist of design, implementation, and evaluation should be applied to know and produce accurate learning. Richards and Rogers (2014, p.215) state that appropriate materials in Content-Based Instruction are materials that are used typically with the subject matter of the content course. Based on the background above, the research has the questions for these researches are:

a. What is the product of English materials development for students at tenth grade of SMA N 1 Metro in Academic Year 2018/2019?

b. How are the experts' validation and students' acceptability for the Android-based English materials at tenth grade of SMA N 1 Metro in Academic Year 2018/2019?

\section{METHODOLOGY}

The researcher develops android-based English learning material for students in X IPS 2 class of SMAN 1 Metro. The method that is used in this research is qualitative method to describe of using android-based English learning material. The subjects of this research research are: (1) an English teacher in X IPS 2 class of SMAN 1 Metro to provide input on the materials use and lecturers majoring in an English education as material experts and media learning experts; (2) the students in X IPS 2 class of SMAN 1 Metro amounted 32 students consist of 20 female students and 12 male students to following the trial of learning media. The object of this research is developing android-based English learning material. The researcher uses questionnaire and interview of this research. 
Developing Android-Based English Learning Material For Students At Tenth Grade Of Senior High School

Syaifudin Latif Darmawan ${ }^{1} \&$ Lilik Wariyanti ${ }^{2}$

\section{FINDINGS}

The results of material expert validation on draft English material, on the conversion of quantitative data scores to qualitative data note that a scoring from expert I is 38 obtained from the contents aspect with the maximum score of 50 so that the a total score of contents aspect is 76 lies in the range 62, $5<\mathrm{x} \leq 81,25$ and the category is "Good". While the aspect of language obtained a score of 20 with the maximum score of 25 so that a total score of language aspect is 80 lies in the range 62, $5<\mathrm{x} \leq 81,25$ and the category is "Good". Moreover, the result of content aspect from expert II obtained a score of 36 with the maximum score of 50 so that a total score of content aspect is 72 lies in the range $62,5<x \leq 81,25$ and the category is "Good". While the result of language aspect obtained a score of 19 with the maximum score of 25 so that a total score of language aspect is 76 lies in the range $62,5<\mathrm{x} \leq 81,25$ and the category is "Good".

The result of material expert validation on draft English material presented in bar chart as follows:

Figure 1.

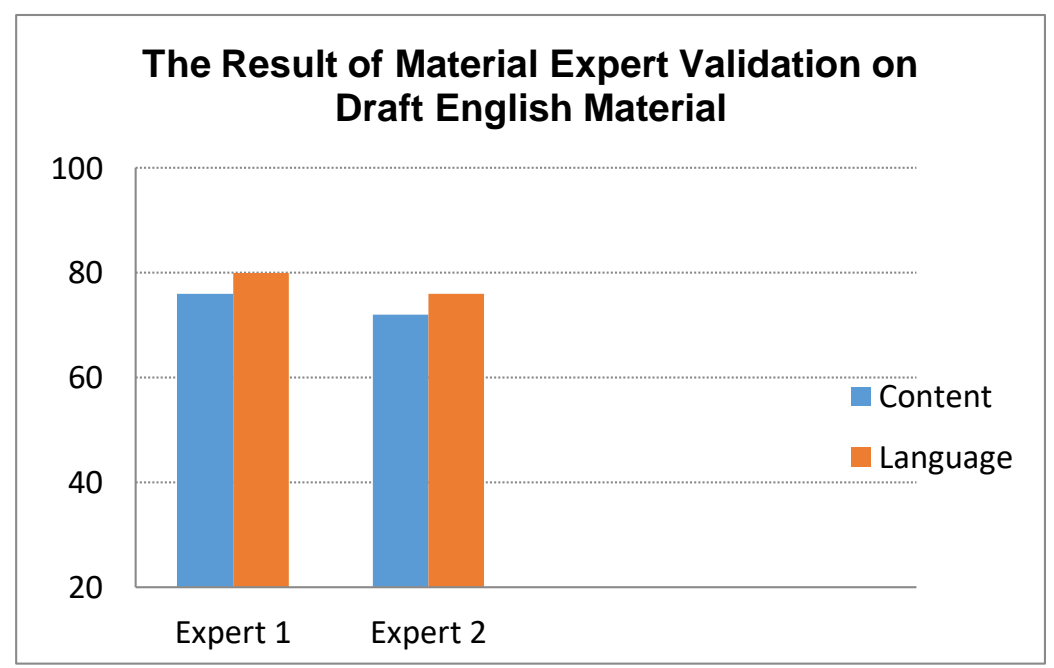


The result of media expert validation on draft English material presented in bar chart as follows:

Figure 2.

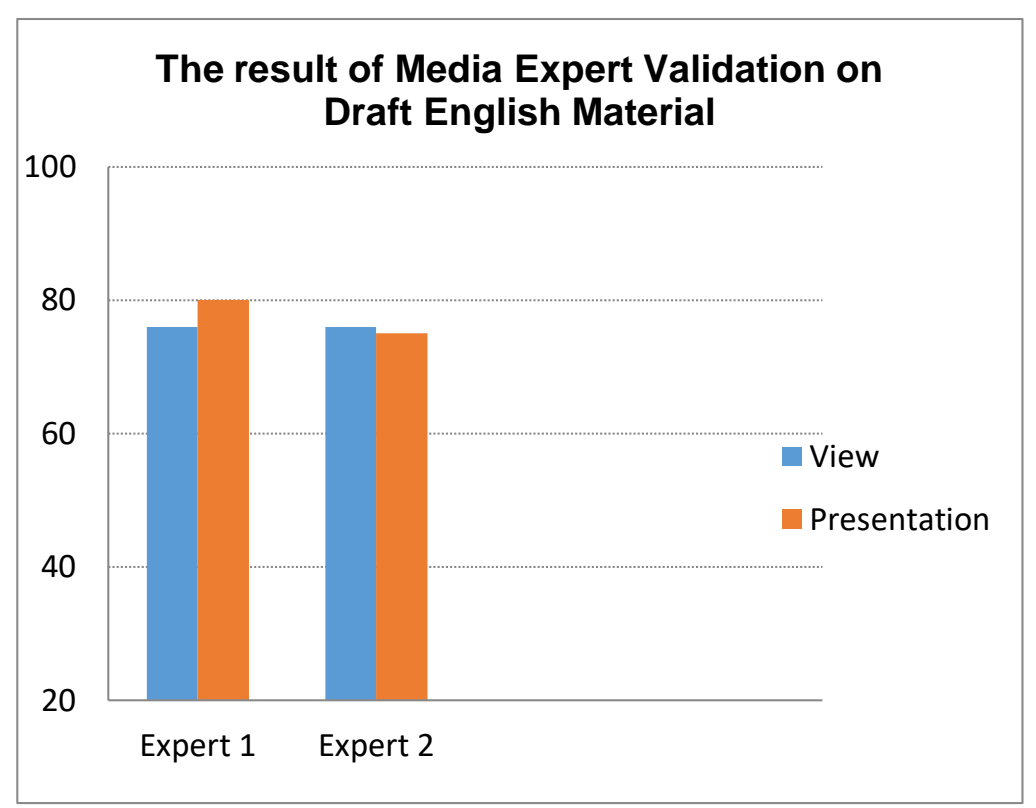

Based on the bar chart above, it can be seen that aspect of view from expert I obtained a score of 23 with the maximal score of 30 so that a total score of view aspect is 76 lies in the range $62,5<\mathrm{x} \leq 81,25$ and the category is "Good". While the aspect of presentation obtained a score of 16 with the maximal score of 20 so that a total score of presentation aspect is 80 lies in the range $62,5<\mathrm{x} \leq 81,25$ and the category is "Good".

Furthermore, the results of view aspect from expert II obtained a score of 23 with the maximal score of 30 so that a total score of view aspect is 76 lies in the range $62,5<\mathrm{x} \leq 81,25$ and the category is "Good". Whereas the result of presentation aspect obtained a score of 15 with the maximal score of 20 so that a total score of presentation aspect is 75 lies in the range $62,5<\mathrm{x} \leq 81,25$ and the category is "Good". Based on the result both of expert I and expert II can be concluded the level of feasibility on draft English material is "Good". 
Developing Android-Based English Learning Material For Students At Tenth Grade Of Senior High School

Syaifudin Latif Darmawan ${ }^{1} \&$ Lilik Wariyanti ${ }^{2}$

The result of material expert validation on Android-based English Material presented in bar chart as follows

Figure 3.

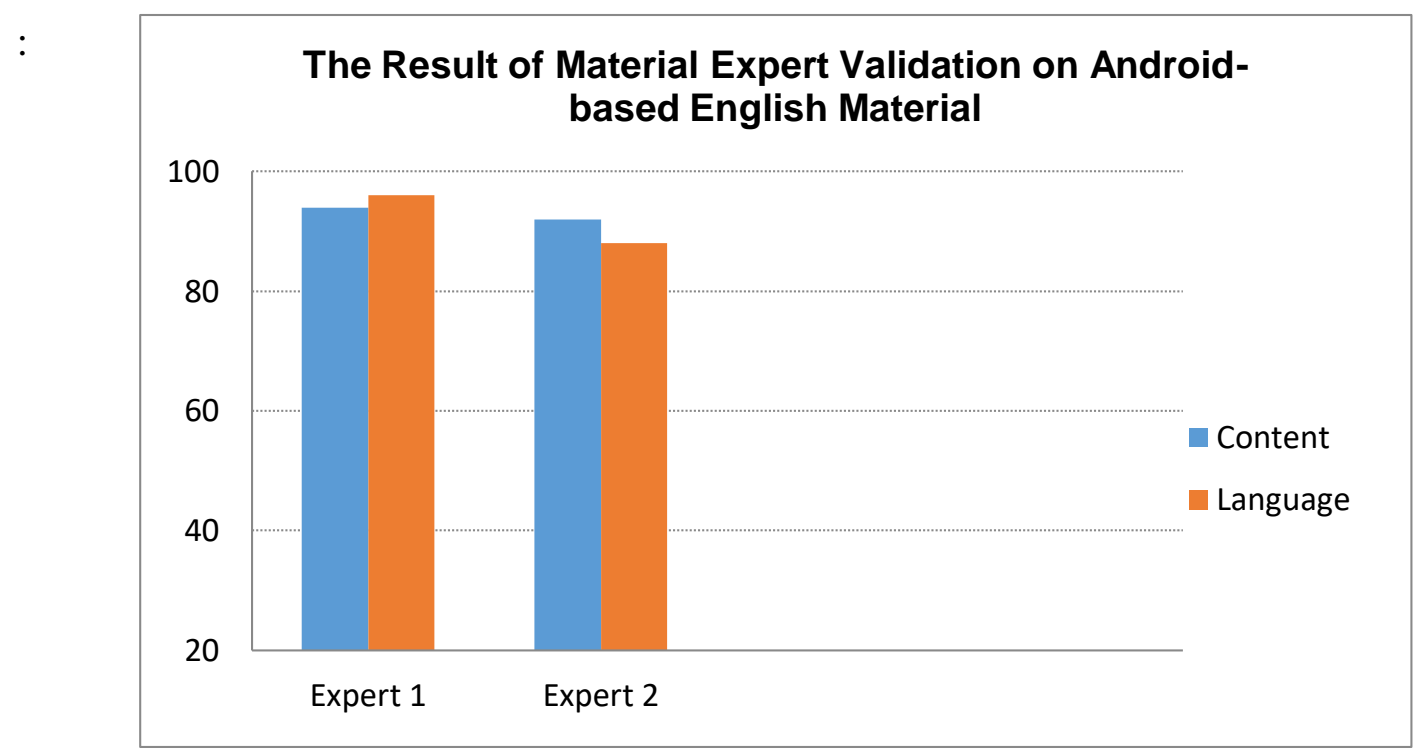

It can be seen that aspect of content from expert I obtained a score of 47 with the maximal score of 50 so that a total score of content aspect is 94 lies in the range $81,25<x \leq 100$ and the category is "Very Good". While the result of language aspect obtained a score of 24 with the maximal score of 25 so that the result of language aspect is 96 lies in the range $81,25<\mathrm{x}$ $\leq 100$ and the category is "Very Good".

Furthermore, the result of content aspect from expert II obtained a score of 46 with the maximal score of 50 so that a total score of content aspect is 92 lies in the range $81,25<x \leq$ 100 and the category is "Very Good". Whereas the result of language aspect obtained a score of 22 with the maximal score of 25 so that a total score of language aspect is 88 lies in the range $81,25<\mathrm{x} \leq 100$ and the category is "Very Good". 
The result of media expert validation on Android-based English material presented in bar chart as follows:

Figure 4.

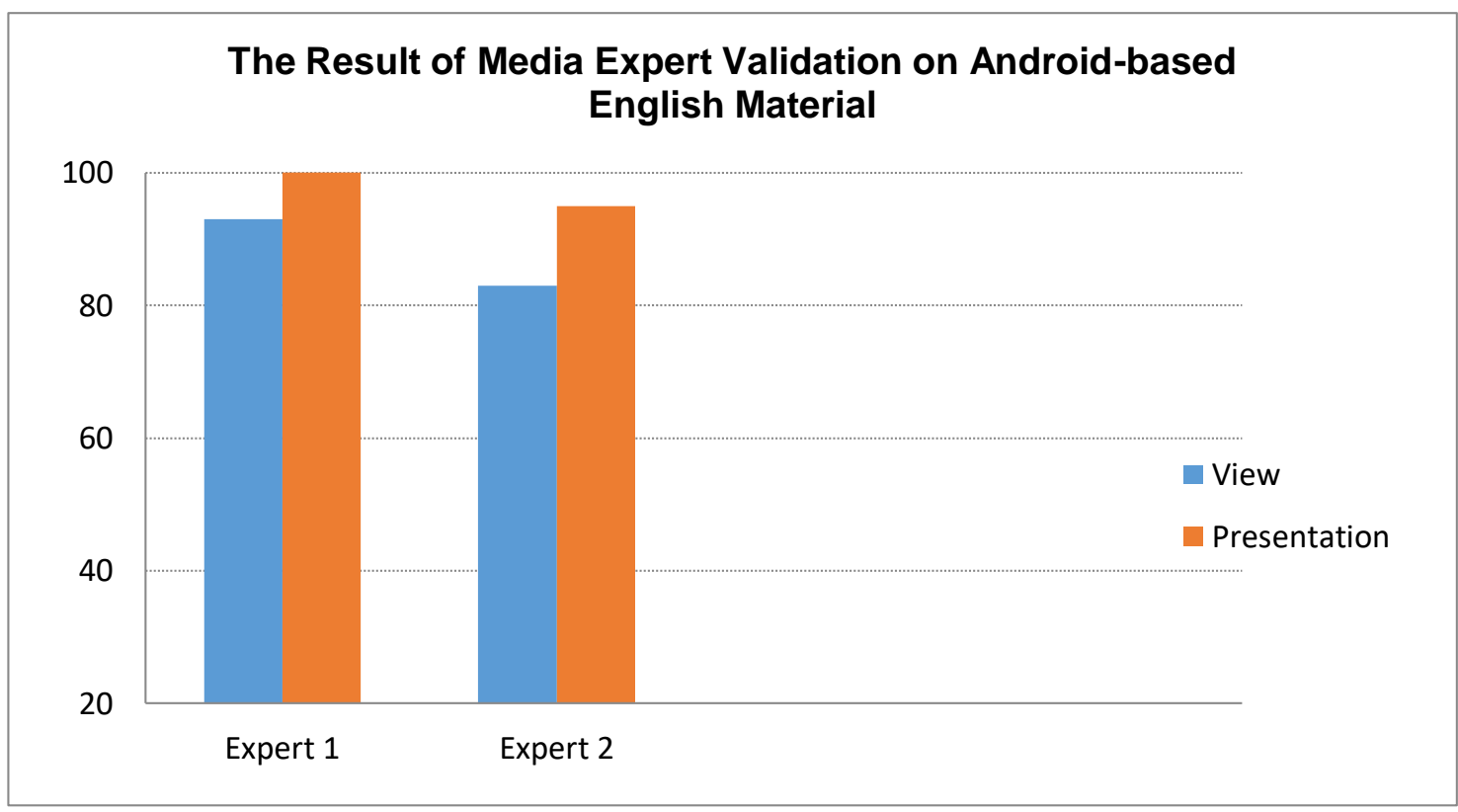

Based on the bar chart above, the result of media expert validation on the conversion of quantitative data scores to qualitative data note that view aspect obtained a score of 28 from expert I with the maximal score of 30 so that a total score of view aspect is 93 lies in the range $81,25<\mathrm{x} \leq 100$ and the category is "Very Good". While the result of presentation aspect obtained a score of 20 with the maximal score of 20 so that a total score of presentation aspect is 100 lies in the range $81,25<\mathrm{x} \leq 100$ and the category is "Very Good".

In addition, the result of view aspect from expert II obtained a score of 25 with the maximal score of 30 so that a total score of view aspect is 83 lies in the range $81,25<x \leq$ 100 and the category is "Very Good". Whereas the result of presentation aspect obtained a score of 19 with the maximal score of 20 so that a total score of presentation aspect is 95 lies in the range 81, $25<\mathrm{x} \leq 100$ and the category is "Very Good". Based on the result both of expert I and expert II indicated that android-based English material is appropriateness to be applied in learning process. 
Developing Android-Based English Learning Material For Students At Tenth Grade Of Senior High School

Syaifudin Latif Darmawan ${ }^{1} \&$ Lilik Wariyanti ${ }^{2}$

The result of students' responses on Android-based English material presented in bar chart as follows:

Figure 5.

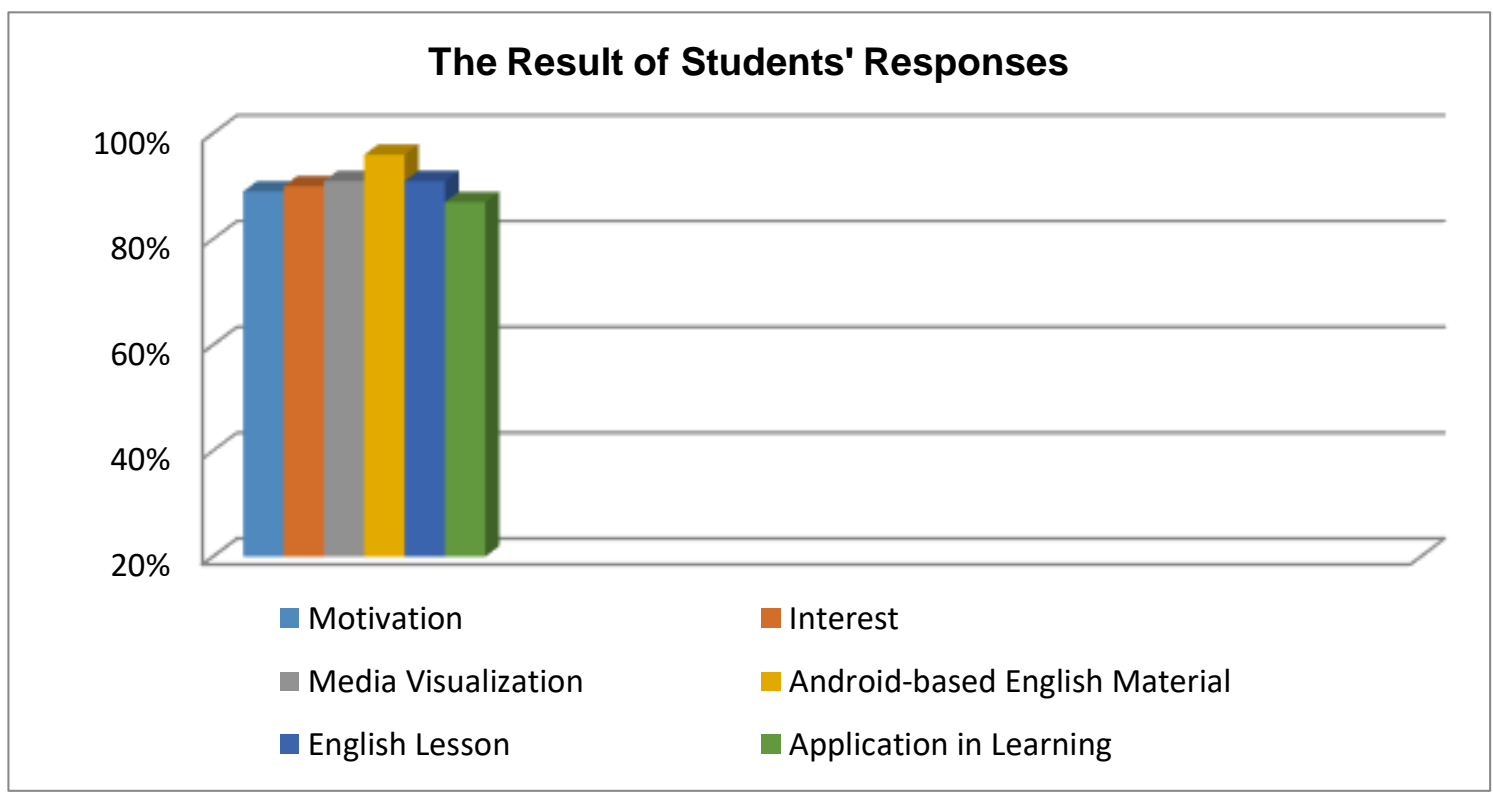

Based on the bar chart above, it can be seen that students' responses on Android-based English learning material on the conversion of quantitative data scores to qualitative data note that a total score of 142 obtained from the motivation aspect with percentage of $89 \%$ and the category is "Very Good". Meanwhile, an aspect of interest obtained a total score of 287 with percentage of $90 \%$ and the category is "Very Good". For media visualization aspect obtained a total score of 146 with percentage of $91 \%$ and the category is "Very Good". Furthermore, an aspect of Android-based English learning material obtained a total score of 154 with percentage of $96 \%$ and the category is "Very Good". Whereas, an aspect of English lesson obtained a total score of 438 with percentage of $91 \%$ and the category is "Very Good". The last is application in learning aspect obtained a total score of 279 with percentage of $87 \%$ and the category is "Very Good". Based on a questionnaire response that has been filled by the students in IPS 2 class of SMAN 1 Metro showed the Android-based English learning material developed with obtained a total score of motivation, interest, media visualization, Android-based English learning material, English lesson, and application in learning aspect are 1446 with percentage of $90 \%$ an overall category of students' responses to application is "Very Good". 


\section{CONCLUSION}

Based on the data result, it can be concluded that material expert validation I on Android-based English material in content aspect obtained a total score of 94 with the category is "Very Good", while the aspect of language obtained a total score of 96 with the category is "Very Good". Furthermore, the result of material expert validation II in content aspect obtained a total score of 92 with the category is "Very Good", whereas the aspect of language obtained a total score of 88 with the category is "Very Good".

Moreover, the result of media expert validation I on android-based English material in view aspect obtained a total score of 93 with the category is "Very Good", while the aspect of presentation obtained a total score of 100 with the category is "Very Good". Furthermore, the result of media expert validation II in view aspect obtained a total score of 83 with the category is "Very Good", whereas the aspect of presentation obtained a total score of 95 with the category is "Very Good" so that the level of feasibility on android-based English material at tenth grade of senior high school obtained the category "Very Good".

Furthermore, the students' responses on Android-based English learning material showed an aspect of motivation, interest, media visualization, Android-based English material, English lesson, and application in learning is "Very Positive". A total score of students" responses is 1446 and percentage $90 \%$ which lies in the range $81 \% \leq$ skor $\leq 100 \%$. It means that Android-based English learning material is worth to use for students at tenth grade of senior high school.

The results of interview can be concluded that students are passionate when following the learning process by using application and according to the students, application is easy to used, interesting, and practically. It means the results of interview to the students as a whole showed a good response on Android-based English material in learning process at tenth grade of senior high school.

\section{REFERENCES}

Aritonang. (2014). Beginning Android Programming with ADT Bundle: Panduan Lengkap untuk Menjadi Android Programmer. Jakarta: Elek Media Computindo.

Musahrain. (2016). Developing Android-Based Mobbil Learning as a Media in Teaching English. Sebelas Maret University. 
Developing Android-Based English Learning Material For Students At Tenth Grade Of Senior High School

Syaifudin Latif Darmawan ${ }^{1} \&$ Lilik Wariyanti ${ }^{2}$

Saefi, Muhammad. (2017). Developing Android-based Mobile Learning On Cell Structure and Function Lesson Subject Topic to Optimize Grade XI Students' Cognitive Comprehension. Universits Muhammadiyah Malang.

Tarmizi. (2013). Application Based Android as a Development of English Learning Media. University of Lampung.

Tomlinson. (2015). Materials Development in Language Teaching. United Kingdom: Cambridge University Press. 